\title{
Dose dependent effects of chronic exposure to toluene on neuronal and glial cell marker proteins in the central nervous system of rats
}

\author{
Jian Huang, Nobuyuki Asaeda, Yasuhiro Takeuchi, Eiji Shibata, Naomi Hisanaga, Yuichiro \\ Ono, Kanefusa Kato
}

\begin{abstract}
The dose dependent effects of chronic exposure to toluene on the neuronal marker proteins $(\gamma-$ enolase, calbindin-D28k) and glial cell marker proteins $(\alpha$-enolase, creatine kinase-B, and $\beta$ $S 100$ protein) were investigated in the central nervous system (CNS) of rats. Three groups of animals were exposed to $100 \mathrm{ppm}, 300 \mathrm{ppm}$, or 1000 ppm toluene vapour eight hours a day, six days a week for 16 weeks. The contents of the marker substances were determined with enzyme immunoassays. A significant increase in the three glial cell marker proteins was noted in the cerebellum after exposure to 100 ppm toluene; a more pronounced increase occurred at the higher toluene concentrations. $\beta-S 100$ protein also exhibited a dose dependent increase in the brainstem and spinal cord. On the other hand, the two neuronal cell markers did not show a quantitative decrease in the CNS. This means that the development of gliosis, rather than neurone death, is induced by chronic exposure to toluene. The significant biochemical changes induced around the threshold limit value and the concentration dependent alterations suggest that these nerve specific marker proteins may be used to evaluate solvent related damage to the CNS.
\end{abstract}

Toluene is one of the most widely used aromatic solvents in industry, and it has a high potential for

Department of Hygiene, Nagoya University School of Medicine, 65 Tsurumai-cho, Showa-ku, Nagoya 466, Japan

J Huang, N Asaeda, Y Takeuchi, E Shibata, N Hisanaga, Y Ono

Department of Biochemistry, Institute for Development Research, Aichi Prefectural Colony, Kasugai, Aichi, Japan

K Kato abuse. Although a number of case reports and epidemiological surveys indicate that toluene exerts its main toxic effects on the central nervous system (CNS), ${ }^{1}$ the toxic mechanism, the early and subclinical response to chronic low level exposure, and the dose effect relations are poorly defined. The evaluation of solvent related CNS toxicity is difficult due to the lack of sensitive and specific indices to detect the early and selective lesions of nervous tissue. Recently, several studies have been conducted to determine the effects of toluene on the composition of brain lipid, ${ }^{2}$ protein phosphorylation, ${ }^{3}$ monoamine metabolism, ${ }^{4}$ and behaviour of neurotransmitters. ${ }^{5}$ The neurochemical methods used, however, generally did not identify the specific types or classes of neuronal cells that are affected by neurotoxic agents. Recent progress in neurochemistry and immunohistology has confirmed that some isoenzymes or isoproteins are specifically distributed in cells of the CNS. Neurone specific $\gamma$-enolase, the enolase isozyme containing the $\gamma$-subunit, is localised in the cytoplasm of neurones, whereas $\alpha$-enolase, which consists of the $\alpha$-subunit, is primarily localised in glial cells in the CNS. ${ }^{6}$ On the other hand, calbindinD28k and $\beta$-S100 protein belong to a family of calcium binding proteins, but have different cellular localisation in the CNS. Calbindin-D28k is localised in the cytoplasm of neurones whereas $\beta$-S100 protein is found in astroglia. ${ }^{78}$ Also, creatine kinase-B, a brain type glycolytic enzyme with the $\beta$-subunit of $\mathrm{CK}$ isozyme, is also known to be located primarily in glial cells. ${ }^{9}$ Highly sensitive immunoassay systems for determining these specific marker proteins have been developed with detection limits in the picogram range. ${ }^{10}$

The specific cellular distribution of these proteins in the nervous system and the establishment of sensitive immunoassay systems for them have made it possible to investigate the biochemical basis of solvent related neurotoxicity. In our previous study, we found that inhalation of toluene for two weeks could induce dose dependent changes in these 
neuronal and glial cell marker proteins in separate rat brain regions. ${ }^{11}$ In the present study, we focused our attention on the dose dependent effects of chronic exposure to toluene for 16 weeks. We attempted to clarify the biochemical response pattern in different types of nerve cells and different regions of the CNS after prolonged toluene treatment.

\section{Materials and methods}

\section{ANIMALS AND EXPOSURE TO SOLVENTS}

Thirty two specific pathogen free male Wistar rats (about $300 \mathrm{~g}$ body weight; Shizuoka Laboratory Animal Centre) were randomly divided into four equal groups, and were acclimatised to the animal facility for one week before initial exposure. One group was exposed to $100 \mathrm{ppm}$, one to $300 \mathrm{ppm}$, and one to $1000 \mathrm{ppm}$ toluene vapour (99\% pure, Katayama Chemical $\mathrm{Co}$ ) in stainless steel inhalation chambers $(80 \times 80 \times 58 \mathrm{~cm})$. Exposure was for eight hours a day, six days a week, for 16 weeks. The control group was housed in an identical chamber ventilated with fresh air. The environment was kept on a 12 hour light dark cycle (lights on at 900 and off at 2100 ), and held at $20-21^{\circ} \mathrm{C}$ and $57-60 \%$ humidity. All animals had free access to food pellets and water during the test period.

The inhalation exposure system used in this study was the same as that described in our previous reports. ${ }^{112}$ The amount of solvent injected into the evaporators was automatically controlled by a computer system that constantly monitored the information on chamber concentration as supplied by a gas chromatograph (Shimadzu GC-8A). The long term stability of the system allowed the concentration of solvent to be kept within $5 \%$ of the target concentration. The time weighted average concentrations of toluene during the whole exposure period in the three treatment groups were $100 \mathrm{ppm}$ (standard deviation (SD) $2 \mathrm{ppm}$ ), $302 \mathrm{ppm}$ (SD $6 \mathrm{ppm}$ ), and $1003 \mathrm{ppm}$ (SD $24 \mathrm{ppm}$ ).

\section{TISSUE PREPARATIONS}

Body weight gain of the animals was measured once every two weeks. The rats were killed by decapitation about 48 hours after the last exposure. The brain and spinal cord (at the S5-S7 level) were rapidly removed and weighed. The brains were immediately dissected into cerebral hemisphere, cerebellum, and brainstem (medulla oblongata, pons, and peduncle) on an ice plate. Tissues of brain and spinal cord were kept frozen at $-30^{\circ} \mathrm{C}$ until analysis of the marker proteins.

IMMUNOASSAY OF NERVE SPECIFIC MARKER PROTEINS Tissues were homogenised with a teflon-glass homogeniser at $0^{\circ} \mathrm{C}$ in 10 volumes of $50 \mathrm{mM}$ Tris $\mathrm{HCl}$ buffer $(\mathrm{pH} \mathrm{7.5)}$ containing $5 \mathrm{mM} \mathrm{MgCl}$. The homogenates were centrifuged at $15000 \mathrm{~g}$ for 20 minutes at $4^{\circ} \mathrm{C}$. The supernatants were used for the assays of the nerve specific proteins, and for the estimation of soluble protein concentrations.

Two neuronal marker proteins ( $\gamma$-enolase, calbindin-D28k) and three glial cell marker proteins ( $\alpha$ enolase, creatine kinase-B, $\beta$-S100 protein) were determined by means of sandwich type enzyme immunoassay systems. Details of these are described elsewhere. ${ }^{13-16}$ Briefly, they consisted of a solid phase (polystyrene balls) with immobilised rabbit antibodies monospecific to the respective subunit of enolase ( $\gamma$ - or $\alpha$-enolase), creatine kinase-B, $\beta$-S100 protein, and calbindin-D28k, and the same antibodies labelled with $\beta$-D-galactosidase from $\mathrm{E}$ coli.

The extract of the tissues was diluted 100 to 1000

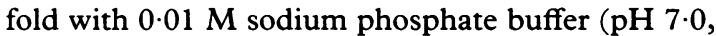
containing $0 \cdot 1 \mathrm{M} \mathrm{NaCl}, 1 \mathrm{mM} \mathrm{MgCl}, 0 \cdot 1 \%$ bovine serum albumin, and $0 \cdot 1 \% \mathrm{NaN}_{3}$ ). Aliquots of $10 \mu \mathrm{l}$ of the diluted sample were subjected to immunoassay with the procedures described by Kato et al. ${ }^{10}$

Standard proteins used for the assays were purified rat $\gamma$-enolase, $\alpha x$-enolase, creatine kinase-BB, calbindin-D28k, and human $\beta \beta-S 100$ protein. The values for each subunit of isoprotein are expressed as $\mu \mathrm{g}$ or $\mathrm{ng}$ of the respective homodimeric isoprotein equivalent per mg soluble protein. Protein concentrations of the soluble fractions of homogenates were estimated by the dye binding method of Bradford ${ }^{17}$ using Bio-Rad reagents.

\section{STATISTICAL ANALYSIS}

The comparisons among multiple groups were performed using one way analysis of variance (ANOVA) followed by the Bonferroni method. ${ }^{18} \mathrm{~A}$ probability of $p<0.05$ was accepted as significant.

\section{Results}

CLINICAL STATE, BRAIN WEIGHTS, AND TOTAL SOLUBLE PROTEIN CONCENTRATIONS

All animals survived the exposure period (16 weeks). Neither signs of peripheral neuropathy nor behavioural abnormalities were seen. We found no significant changes in body weight in any group of exposed animals compared with the controls. The

Table 1 Body and CNS weights of rats after chronic exposure to toluene

\begin{tabular}{|c|c|c|c|c|}
\hline Regions & $\begin{array}{l}\text { Control } \\
\text { (mean } \\
(S E))\end{array}$ & $\begin{array}{l}100 \text { ppm } \\
(\text { mean } \\
(S E))\end{array}$ & $\begin{array}{l}300 \text { ppm } \\
(\text { mean } \\
(S E))\end{array}$ & $\begin{array}{l}1000 \text { ppm } \\
(\text { mean } \\
(S E))\end{array}$ \\
\hline $\begin{array}{l}\text { Body } \\
\text { Whole brain } \\
\text { Cerebrum } \\
\text { Cerebellum } \\
\text { Brainstem }\end{array}$ & $\begin{array}{l}508(21) \\
2.14(0.07) \\
1.26(0.06) \\
0.29(0.02) \\
0.57(0.03)\end{array}$ & $\begin{array}{l}503(45) \\
2.15(0.06) \\
1.27(0.05) \\
0.29(0.01) \\
0.57(0.06)\end{array}$ & $\begin{array}{l}493(38) \\
2.14(0.10) \\
1.25(0.07) \\
0.29(0.01) \\
0.58(0.04)\end{array}$ & $\begin{array}{l}489(34) \\
2.12(0.07) \\
1.20(0.04) \\
0.29(0.02) \\
0.59(0.03)\end{array}$ \\
\hline
\end{tabular}

No significant difference was found between exposed animals and controls.

For each group $\mathbf{n}=8$; all results are $\mathrm{g}$. 
weights of whole brain, cerebrum, cerebellum, and brainstem did not differ significantly among the four groups (table 1).

Total soluble proteins per wet weight in the cerebrum and cerebellum were not significantly different between exposed rats and controls. The concentrations of soluble protein in the brainstem and spinal cord were increased only in the $1000 \mathrm{ppm}$ group (table 2).

Table 2 Concentrations of total soluble proteins in rat CNS after chronic exposure to toluene

\begin{tabular}{lllll}
\hline Regions & $\begin{array}{l}\text { Control } \\
\text { (mean } \\
(S E))\end{array}$ & $\begin{array}{l}\text { 100 ppm } \\
(\text { mean } \\
(S E))\end{array}$ & $\begin{array}{l}300 \mathrm{ppm} \\
(\text { mean } \\
(S E))\end{array}$ & $\begin{array}{l}1000 \mathrm{ppm} \\
(\text { mean } \\
(S E))\end{array}$ \\
\hline Cerebrum & $25.8(0.9)$ & $24.2(0.8)$ & $25.8(1.6)$ & $22.5(0.6)$ \\
Cerebellum & $24.9(1.1)$ & $22.7(0.4)$ & $22.8(0.2)$ & $22.8(0.4)$ \\
Brainstem & $17.9(0.5)$ & $19.1(0.2)$ & $19.7(0.2)$ & $21.9(0.5)^{\star}$ \\
Spinal cord & $9.3(0.2)$ & $10.2(0.3)$ & $10.4(0.2)$ & $12.3(0.4)^{\star}$ \\
\hline
\end{tabular}

${ }^{\star} \mathrm{p}<0.05$; significantly different from control.

For each group $\mathrm{n}=8$; all results are $\mathrm{mg} / \mathrm{g}$ wet tissue.
EFFECTS OF CHRONIC EXPOSURE TO TOLUENE ON NEURONAL MARKER PROTEINS ( $\gamma$-ENOLASE, CALBINDIN-D28K)

The two neuronal markers did not show any significant changes in cerebrum and brainstem (table 3 ). In the cerebellum, $\gamma$-enolase concentration showed a dose dependent increase, whereas calbindin-D28k concentration remained unchanged. In the spinal cord, $\gamma$-enolase concentration was not significantly changed at any dose, whereas calbindin-D28k concentration was significantly decreased $(17 \%)$ in the 1000 ppm group ( $\mathrm{p}<0.05)$.

EFFECTS OF CHRONIC EXPOSURE TO TOLUENE ON GLIAL CELL MARKER PROTEINS ( $\alpha$-ENOLASE, CREATINE KINASE-B, $\beta$-S100 PROTEIN)

An overall dose dependent increase in the amount of all three glial cell markers was seen in the cerebellum (table 4). A statistically significant increase was noted with exposure to $100 \mathrm{ppm}$ toluene; a more pronounced increase occurred at the higher concentrations. Of the three markers examined, $\beta$-S100 protein

Table 3 Content of neuronal marker proteins in rat CNS after chronic exposure to toluene

\begin{tabular}{|c|c|c|c|c|}
\hline & $\begin{array}{l}\text { Control } \\
(\text { mean }(S E))\end{array}$ & $\begin{array}{l}100 \text { ppm } \\
(\text { mean }(S E))\end{array}$ & $\begin{array}{l}300 \text { ppm } \\
(\text { mean }(S E))\end{array}$ & $\begin{array}{l}1000 \mathrm{ppm} \\
(\text { mean }(S E))\end{array}$ \\
\hline $\begin{array}{l}\text { Cerebrum: } \\
\text { \%-Enolase } \\
\text { Calbindin-D28k }\end{array}$ & $\begin{array}{c}10 \cdot 0(0 \cdot 3) \\
540(13)\end{array}$ & $\begin{array}{c}9 \cdot 8(0 \cdot 3) \\
537(11)\end{array}$ & $\begin{array}{c}9 \cdot 7(0 \cdot 2) \\
565(15)\end{array}$ & $\begin{array}{c}10 \cdot 6(0 \cdot 3) \\
555(11)\end{array}$ \\
\hline $\begin{array}{l}\text { Cerebellum: } \\
\gamma \text {-Enolase } \\
\text { Calbindin-D28k }\end{array}$ & $\begin{array}{l}9 \cdot 6(0 \cdot 4) \\
4 \cdot 15(0 \cdot 14)\end{array}$ & $\begin{array}{c}10 \cdot 7(0.3)^{\star} \\
4.45(0.11)\end{array}$ & $\begin{array}{r}11 \cdot 0(0 \cdot 3)^{\star \star} \\
4.56(0.08)\end{array}$ & $\begin{array}{r}11.2(0.3)^{\star \star} \\
4.55(0.17)\end{array}$ \\
\hline $\begin{array}{l}\text { Brainstem: } \\
\quad \gamma \text {-Enolase } \\
\text { Calbindin-D28k }\end{array}$ & $\begin{array}{c}11 \cdot 7(0 \cdot 2) \\
383(12)\end{array}$ & $\begin{array}{l}11 \cdot 6(0 \cdot 1) \\
376(17)\end{array}$ & $\begin{array}{c}11 \cdot 2(0 \cdot 2) \\
359(11)\end{array}$ & $\begin{array}{c}10 \cdot 9(0 \cdot 3) \\
363(13)\end{array}$ \\
\hline $\begin{array}{l}\text { Spinal cord: } \\
\gamma \text {-Enolase } \\
\text { Calbindin-D28k }\end{array}$ & $\begin{array}{c}16 \cdot 2(0 \cdot 7) \\
196(3)\end{array}$ & $\begin{array}{c}16.9(0.5) \\
185(8)\end{array}$ & $\begin{array}{c}14.9(0.9) \\
188(4)\end{array}$ & $\begin{array}{c}15 \cdot 4(0 \cdot 5) \\
167(8)^{\star}\end{array}$ \\
\hline
\end{tabular}

${ }^{\star} \mathrm{p}<0.05 ;{ }^{\star \star} \mathrm{p}<0.01$; significantly different from control.

For each group $\mathrm{n}=8$. Results for $\gamma$-enolase expressed as $\mu \mathrm{g} / \mathrm{mg}$ soluble protein; for calbindin-D28k as $\mathrm{ng} / \mathrm{mg}$ soluble protein.

Table 4 Content of glial cell marker proteins in rat CNS after chronic exposure to toluene

\begin{tabular}{|c|c|c|c|c|}
\hline & $\begin{array}{l}\text { Control } \\
(\text { mean }(S E))\end{array}$ & $\begin{array}{l}100 \text { ppm } \\
(\text { mean }(S E))\end{array}$ & $\begin{array}{l}300 \text { ppm } \\
(\text { mean }(S E))\end{array}$ & $\begin{array}{l}1000 \mathrm{ppm} \\
(\text { mean }(S E))\end{array}$ \\
\hline $\begin{array}{l}\text { Cerebrum: } \\
\alpha \text {-Enolase } \\
\text { Creatine kinase-B } \\
\beta-S 100 \text { Protein }\end{array}$ & $\begin{array}{l}15.4(0.4) \\
19.5(0.6) \\
3.29(0.17)\end{array}$ & $\begin{array}{l}16 \cdot 0(0 \cdot 7) \\
20 \cdot 3(0 \cdot 5) \\
3 \cdot 60(0 \cdot 25)\end{array}$ & $\begin{array}{l}16.3(0.4) \\
19 \cdot 7(1.0) \\
4.02(0.23)\end{array}$ & $\begin{array}{l}16.3(0.5) \\
20.4(0.6) \\
3.67(0.28)\end{array}$ \\
\hline $\begin{array}{l}\text { Cerebellum: } \\
\alpha \text {-Enolase } \\
\text { Creatine kinase-B } \\
\beta-S 100 \text { Protein }\end{array}$ & $\begin{array}{l}14.7(0.3) \\
26.9(0.7) \\
2.96(0.12)\end{array}$ & $\begin{array}{l}16 \cdot 7(0.6)^{\star} \\
30 \cdot 6(0 \cdot 8)^{\star \star} \\
3.78(0 \cdot 32)\end{array}$ & $\begin{array}{l}17.6(0.5)^{\star \star} \\
32.0(0.8)^{\star \star} \\
4.45(0.12)^{\star \star}\end{array}$ & $\begin{array}{l}17 \cdot 7(0 \cdot 5)^{\star \star} \\
32 \cdot 4(0 \cdot 8)^{\star \star} \\
4 \cdot 79(0 \cdot 33)^{\star \star}\end{array}$ \\
\hline $\begin{array}{l}\text { Brainstem: } \\
\alpha \text {-Enolase } \\
\text { Creatine kinase-B } \\
\beta \text {-S100 Protein }\end{array}$ & $\begin{array}{l}18 \cdot 8(0 \cdot 6) \\
23 \cdot 5(0 \cdot 6) \\
4 \cdot 13(0 \cdot 22)\end{array}$ & $\begin{array}{l}20 \cdot 7(0 \cdot 8) \\
25 \cdot 8(0 \cdot 5) \\
4 \cdot 71(0 \cdot 26)\end{array}$ & $\begin{array}{l}19.7(0.4) \\
23.2(0.7) \\
5.17(0.28)^{\star}\end{array}$ & $\begin{array}{l}19 \cdot 6(0 \cdot 7) \\
22 \cdot 0(0 \cdot 8) \\
5 \cdot 40(0 \cdot 30)^{\star \star}\end{array}$ \\
\hline $\begin{array}{l}\text { Spinal cord: } \\
\alpha-\text { Enolase } \\
\text { Creatine kinase-B } \\
\beta-S 100 \text { Protein }\end{array}$ & $\begin{array}{l}26 \cdot 0(1 \cdot 0) \\
40 \cdot 2(1 \cdot 1) \\
4 \cdot 25(0 \cdot 24)\end{array}$ & $\begin{array}{l}25 \cdot 6(1 \cdot 2) \\
36 \cdot 8(1 \cdot 7) \\
4 \cdot 14(0 \cdot 17)\end{array}$ & $\begin{array}{l}26 \cdot 8(0 \cdot 8) \\
37 \cdot 1(1 \cdot 0) \\
4 \cdot 99(0 \cdot 32)\end{array}$ & $\begin{array}{l}24 \cdot 0(1 \cdot 6) \\
34.5(0 \cdot 8)^{\star} \\
5 \cdot 74(0 \cdot 25)^{\star \star}\end{array}$ \\
\hline
\end{tabular}

${ }^{\star} \mathrm{p}<0.05 ;{ }^{\star} \mathrm{p}<0.01 ;$ significantly different from control.

For each group $\mathrm{n}=8$; all results are $\mu \mathrm{g} / \mathrm{mg}$ soluble protein. 
showed the largest quantitative enhancement $(2 \overline{8} \%$, $50 \%$, and $62 \%$ relative to control concentrations in the $100 \mathrm{ppm}, 300 \mathrm{ppm}$, and $1000 \mathrm{ppm}$ groups respectively). By contrast with the response pattern in the cerebellum, no significant changes in glial cell markers were found in the cerebrum. For the brainstem and spinal cord, only $\beta$-S100 protein concentration was significantly increased in a dose dependent manner. On the other hand, creatine kinase-B concentration showed a significant decrease $(16 \%)$ in the spinal cord of the $1000 \mathrm{ppm}$ toluene group.

\section{Discussion}

There is little doubt that prolonged exposure to high concentrations of toluene such as may occur during glue sniffing can damage the cerebellum and impair the higher integrative functions of the CNS. The effects of chronic low exposure, however, remain controversial, although some neurobehavioural studies suggest impaired functions of the CNS such as disturbances in learning ability, memory loss, changes in balance and coordination of locomotor movements, and high frequency hearing loss. ${ }^{1}$ The biochemical basis for these effects and the doseresponse relation have not been sufficiently explored. Limited pathological examinations have failed to show changes in brain structure after chronic inhalation of $1500-4000 \mathrm{ppm}$ toluene. ${ }^{1920}$ Therefore, the. neurochemical approach becomes important to establish sensitive and specific indicators for the evaluation of this kind of solvent related CNS toxicity.

The present study provides biochemical evidence that long term inhalation of toluene can induce dose dependent changes in nerve specific marker proteins in the rat CNS. No reduction in the concentrations of total soluble protein was found (table 2); this excludes the possibility that quantitative enhancement of markers is due to diminished total protein content. Exposure to as low as $100 \mathrm{ppm}$ toluene, which is the threshold limit value (TLV) set by the American Conference of Governmental Industrial Hygienists and the Japan Industrial Health Association, was found to produce a significant effect on glial cell markers in the cerebellum (table 4). Euler $e^{2} a^{4}$ reported that exposure of old rats to toluene for three months at doses of $80 \mathrm{ppm}$ could induce region specific effects on pre and postsynaptic parameters of catacholamine and neuropeptide transmission. Some epidemiological evidence also exists for an increased risk of neuropsychiatric disorders among workers chronically exposed to toluene below or around the TLV. ${ }^{2122}$ The present study is in accordance with these investigations, which suggest that chronic low exposure to toluene around the TLV might have a potentiating effect on the CNS.

We also noted that the patterns of neurotoxic response to chronic exposure to toluene differ in different areas of the CNS. The fact that the most pronounced increase in glial cell markers occurred in the cerebellum agrees with results of our previous subacute experiment. ${ }^{11}$ Many case reports of toluene sniffing show that cerebellar abnormalities are the most commonly and convincingly described disorders among the persistent neurological deficits attributed to high exposure to toluene. ${ }^{23}$ Some clinical investigations on industrial workers ${ }^{24}$ and animals ${ }^{25}$ also suggest the involvement of a cerebellar mechanism in toluene or toluene containing solvent induced disturbance of the vestibulo-oculomotor system. The present results support these clinical observations, and indicate the vulnerability of the cerebellum to toluene in animals under conditions comparable to occupational exposure. As well as the effects on the cerebellum, brainstem, and spinal cord, we also found dose dependent changes in $\beta$-S100 protein concentration. By contrast, amounts of marker substances examined in the cerebrum remained the same whatever the dose of toluene. This suggests that the cerebrum is less vulnerable to toluene than other areas of the CNS.

The enzyme immunoassay systems used are capable of identifying the specific cellular elements of neurones and glial cells. With the exception of calbindin-D28k in the spinal cord, the two neuronal cell markers did not show a quantitative decrease. This means that obvious neuronal loss or degeneration had not yet occurred by the time of death under the treatment schedule employed. Korbo et al $l^{26}$ also reported that the total number of neurones in the cortex of rat brain did not show any decrease after 12 weeks of toluene administration. By contrast, the glial cell marker proteins displayed a definite dose dependent tendency to increase in the cerebellum, brainstem, and spinal cord. The development of gliosis is considered as an explanation for this phenomenon. Progressive reactions of the glial cells, including hypertrophy or proliferation, commonly follow damage to the CNS such as traumatic destruction, degenerative disorders, and infectious diseases, ${ }^{27}$ and may result in the enhancement of the glial cell marker substances. The glial cell reactions after chronic exposure to chlorinated solvents, styrene, and toluene have also been proposed as an explanation by other authors. ${ }^{28-30}$ Gliosis may be a common and early finding indicative of solvent related effects on the CNS.

The possible mechanisms for gliosis include a primary action of neurotoxins on the glial cells, or a secondary indirect action responding to neuronal damage. The dose dependent increases in glial cell markers and the maintenance of neuronal markers in the rat CNS support the idea of direct action of toluene on glial cells.

It should be noted, however, that $\gamma$-enolase, a neurone-specific marker, also exhibited a significant 
increasing trend in the cerebellum. Reactive astrocytes are reported to be capable of producing neurone-specific enolase that normally exists only in neurones. ${ }^{31}$ Therefore, the glial reaction induced by toluene treatment may partly contribute to the increase in $\gamma$-enolase concentration.

Interference with the energy metabolism of the CNS by toluene is speculated to be another explanation for the changes in $\gamma$-enolase, $\alpha$-enolase, and creatine kinase-B concentrations, considering that all three proteins are glycolytic enzymes that play an important part in energy supply within the CNS. Sabri and Spencer ${ }^{32}$ indicated that disturbance of the energy metabolism may be one of the aetiological factors in the development of organic solvent neurotoxicity. The disruption of energy metabolism in the brain, which might occur under the high toluene exposure, and the heightened metabolic state arising from gliosis, may provoke the compensatory oversynthesis of glycolytic enzymes to satisfy the energy demand.

In summary, the present study found a dose dependent increase in glial cell markers and the relative maintenance of neuronal markers in the CNS of rats after chronic repeated exposure to toluene. This would mean that gliosis, rather than neuronal death, can be induced by toluene at exposure concentrations comparable with occupational conditions. Among the various CNS regions examined, the cerebellum is the most affected by treatment with toluene, whereas the cerebrum seems to be less vulnerable. Moreover, the significant changes induced by a dose as low as $100 \mathrm{ppm}$, together with the concentration dependent alterations, suggest that these nerve specific marker proteins may be used to evaluate solvent induced damage to the CNS.

This work was supported by a research grant from the Ministry of Education, Science and Culture of Japan (No 02454200 and No 03770280).

Requests for reprints to: Jian Huang $\mathrm{MD}, \mathrm{PhD}$, Department of Hygiene, Nagoya University School of Medicine, 65 Tsurumai-cho, Showaku, Nagoya 466, Japan.

1 Antti-Poika M. Toluene, In: Snyder S. ed. Ethel Browning's toxicity and metabolism of industrial solvents. Vol 1 . Amsterdam: Elsevier Science Publishers 1987:38-63.

2 Kyrklund T, Kjellstrand P, Haglid K. Brain lipid changes in rats exposed to xylene and toluene. Toxicology 1987;45:123-33.

3 Von Euler G, Fuxe K, Hansson T, Benfenati F, Agnati LF, Gustafsson JA. Effects of subacute toluene exposure on protein phosphorylation levels in rat frontoparietal and striatal membranes. Acta Physiol Scand 1988;131:113-8.

4 Von Euler G, Fuxe K, Hansson T, et al. Effects of chronic toluene exposure on central monoamine and peptide receptors and their interactions in the adult male rat. Toxicology 1988;52:103-26.

5 Honma $T$, Sudo A, Miyagawa $M$, Sato $M$, Hasegawa $H$. Significant changes in the amounts of neurotransmitter and related substances in rat brain induced by subacute exposure to low levels of toluene and xylene. Ind Health 1983;21:143 51 .

6 Schmechel D, Marangos PJ, Zis AP, Brightman M, Goodwin FK. Brain enolases as specific markers of neuronal and glial cells. Science 1978;199:313-5.

7 Cicero TJ, Cowan W, Moore BW, Suntzeff V. The cellular localization of the two brain specific proteins, $S-100$ and $14-3-$
2. Brain Res 1970;18:25-31.

8 Christakos S, Gabrielides C, Rhoten WB. Vitamin D-dependent calcium binding proteins: chemistry, distribution, functional considerations and molecular biology. Endocr Rev 1989;10: 3-26.

9. Chandler WL, Clayson KJ, Longstreth WT, Fine JS. Creatine kinase isoenzymes in human cerebrospinal fluid and brain. Clin Chem 1984;30:1804-10.

10 Kato K. Enzyme immunoassay and nervous tissue-related proteins. Protein, neucleic acid and enzyme 1990;35:612-21. (In Japanese.)

11 Huang J, Kato K, Shibata E, Hisanaga N, Ono Y, Takeuchi Y. Effects of subacute toluene exposure on neuronal and glial marker proteins in rat brain. Toxicology 1990;61:109-17.

12 Takeuchi Y, Huang J, Shibata E, Hisanaga N, Ono Y. A trial to automatize an organic solvent exposure system for small animals. Japan Journal of Industrial Health 1989;31:722. (In Japanese.)

13 Kato K, Suzuki F, Umeda Y. Highly sensitive immunoassay for three forms of rat brain enolase. $J$ Neurochem 1981;36:793-7.

14 Kato $K$, Nakajima T, Ishiguro Y, Matsutani T. Sensitive enzyme immunoassay for $S-100$ protein: determination in human cerebrospinal fluid. Biomedical Research 1982;3:24-8.

15 Kato K, Suzuki F, Shimizu A, Shinohara H, Semba R. Highly sensitive immunoassay for rat brain-type creatine kinase: determination in isolated Purkinje cells. $J$ Neurochem 1986;46:1783-8.

16 Kurobe N, Shinohara H, Semba R, Inagaki T, Kato K. Sensitive enzyme immunoassay for rat $28 \mathrm{kDa}$ calcium-binding protein: developmental and age-dependent changes in the central nervous tissue. Bulletin of the Japanese Neurochemical Society 1990;29:474-5.

17 Bradford MM. A rapid and sensitive method for the quantitation of microgram quantities of protein utilizing the principle of protein-dye binding. Anal Biochem 1976;72:248-54.

18 Wallenstein S, Zucker CL, Fleiss JL. Some statistical methods useful in circulation research. Circ Res 1980;47:1-9.

19 Spencer PS. Experimental evaluation of selected petrochemicals for subchronic neurotoxic properties. In: MacFarland $\mathrm{HN}$, et al eds, Toxicology of petroleum hydrocarbons. Washington DC: American Petroleum Institute, 1982:249-60.

20 Bruckner JV, Peterson RG. Evaluation of toluene and acetone inhalant abuse. 2. model development and toxicology. Toxicol Appl Pharmacol 1981;61:302-12.

21 Foo SC, Phoon WO, Lee J. Neurobehavioral symptoms among workers occupationally exposed to toluene. Asia-Pacific Journal of Public Health 1988;2:192-7.

22 Orbeak P, Nise G. Neurasthenic complaints and psychometric function of toluene-exposed rotogravure printers. $\mathrm{Am} \mathrm{J}$ Ind Med 1989;16:67-77.

23 Ron MA. Volatile substance abuse: a review of possible longterm neurological, intellectual and psychiatric sequelae. $\mathrm{Br} J$ Psychiatry 1986;148:235-46.

24 Odkvist LM, Arlinger SD, Edling C, Larsby B, Bergholtz LM. Audiological and vestibulo-oculomotor findings in workers exposed to solvents and jet fuel. Scand Audiol 1987;16:75-81.

25 Larsby B, Tham R, Eriksson B, Odkvist LM. The effect of toluene on the vestibulo-and opto-oculomotor system in rats. Acta Otolaryngol (Stockh) 1986;101:422-4.

26 Korbo L, Pakkenberg B, Ladefoged L, Gundersen HG, ArlienSoborg P, Pakkenberg $\mathrm{H}$. An efficient method for estimating the total number of neurons in rat brain cortex. $J$ Neurosci Methods 1990;31:93-100.

27 Duchen LW. General pathology of neurons and neuroglia. In: Adams JH, Corsellis JAN, Duchen LW, eds. Greenfield's neuropathology. London: Edward Arnold, 1984:1-52.

28 Rosengren LE, Aurell A, Kjellstrand P, Haglid KG. Astrogliosis in the cerebral cortex of gerbils after long-term exposure to 1,1,1-trichloroethane. Scand J Work Environ Health 1985; 11:447-55.

29 Rosengren LE, Haglid KG. Long term neurotoxicity of styrene. A quantitative study of glial fibrillary acidic protein (GFA) and S-100. Br J Ind Med 1989;46:316-20.

30 Bjornaes S, Unninaalsund L. Biochemical changes in different brain areas after toluene inhalation. Toxicology 1988;49: 367-74.

31 Vinores SA, Bonnin JM, Rubinstein LJ, Marangos PJ. Immunohistochemical demonstration of neuron-specific enolase in neoplasms of the CNS and other tissues. Arch Pathol Lab Med 1984;108:536-40.

32 Sabri MI, Spencer PS. Toxic distal axonopathy: biochemical studies and hypothetical mechanisms. In: Spencer PS, Schaumburg $\mathrm{HH}$, eds, Experimental and clinical neurotoxicology, London: Williams and Wilkins, 1980:206-19.

Accepted 22 July 1991 